\title{
Effect of Nitromethane and Jatropha Biodiesel on the Combustion, Performance and Emission Characteristics of Diesel Engine
}

\author{
A.V. Berenjestanaki ${ }^{*}$ and D. Husain ${ }^{2}$ \\ ${ }^{1}$ Department of Mechanical Engineering, Aligarh Muslim University, Aligarh 202001, India \\ ${ }_{2}^{2}$ Maulana Mukhtar Ahmad Nadvi Technical campusm, Malegaon, Maharashtra 423203, India
}

ABSTRACT - The experimental work reported has been carried out in two parts; Jatropha biodiesel production and engine test. The engine test has been carried out on a direct injection, single-cylinder, water-cooled stationary diesel engine. Several diesel fuel blends which contain $10 \%$ and $20 \%$ by volume of JBD and $1 \%$ and $3 \%$ nitromethane were prepared. The effects of these blends on the combustion, performance, and emission characteristics of diesel engine were studied. The tests were performed under constant speed and varying load conditions without altering injection timing. A maximum increase of $11.73 \%, 3.2 \%$ and $7.68 \%$ in the brake thermal efficiency, the brake specific fuel consumption and exhaust gas temperature were achieved respectively for $20 \%$ Jatropha biodiesel and $3 \%$ nitromethane at full engine load. Compared to the pure diesel operation, the peak in-cylinder pressure of blended fuels was lower at the full load conditions. Also, the maximum net heat release rate of blended fuels was lower than that of diesel at all loading conditions. In regards to the engine emissions, the results showed that the blended fuels reduced carbon monoxide at 18.6-28.9\% and unburned hydrocarbon of $7.5-24.2 \%$, while increased the emission of nitrogen oxides at $6.9-14.3 \%$ and carbon dioxide at $4.3-10.5 \%$.

ARTICLE HISTORY

Received: $6^{\text {th }}$ Feb 2020

Revised: $9^{\text {th }}$ July 2021

Accepted: $22^{\text {nd }}$ July 2021

\section{KEYWORDS}

Diesel engine;

Jatropha;

Biodiesel;

Nitromethane;

Emissions

\section{NOMENCLATURE}

\begin{tabular}{|c|c|c|c|}
\hline${ }^{\circ} \mathrm{CA}$ & crank angle degree & JBD & Jatropha biodiesel \\
\hline $\mathrm{BSFC}$ & brake specific fuel consumption & BTE & brake thermal efficiency \\
\hline $\mathrm{CO}$ & carbon monoxide & $\mathrm{CO}_{2}$ & carbon dioxide \\
\hline $\mathrm{CN}$ & cetane number & DME & dimethyl ether \\
\hline DI & direct injection & EGT & exhaust gas temperature \\
\hline $\mathrm{KOH}$ & potassium methoxide & MXEE & methoxide ethyl ether \\
\hline $\mathrm{NaOH}$ & sodium hydroxide & $\mathrm{NO}_{\mathrm{X}}$ & nitrogen oxides \\
\hline PM & particulate matter & ROHR & rate of heat release \\
\hline RTDs & resistance temperature detectors & CI & compression ignition \\
\hline ID & ignition delay & $\mathrm{NE}$ & nitro ethane \\
\hline NDIR & non-dispersive infrared & $\gamma$ & specific heat ratio \\
\hline $\mathrm{BDE}$ & biodiesel dimethyl ether & & \\
\hline B10 & $10 \%$ Jatropha biodiesel $+90 \%$ diesel & & \\
\hline $\mathrm{B} 20$ & $20 \%$ Jatropha biodiesel $+80 \%$ diesel & & \\
\hline B10NM1 & $10 \%$ Jatropha biodiesel $+1 \%$ nitrome & diesel & \\
\hline B10NM3 & $10 \%$ Jatropha biodiesel $+3 \%$ nitrome & diesel & \\
\hline B20NM1 & $20 \%$ Jatropha biodiesel $+1 \%$ nitrome & diesel & \\
\hline B20NM3 & $20 \%$ Jatropha biodiesel $+3 \%$ nitrome & diesel & \\
\hline
\end{tabular}

\section{INTRODUCTION}

Internal combustion engines have been used extensively to fulfil society's needs for power and transportation [1]. However, the number of vehicles and further fuel demands are increasing every day. Therefore, many countries trying to develop alternative fuel technology for their vehicles. These days, diesel engines are using in the automotive area, passenger cars as well as heavy-duty, owing to the better fuel economy. However, there are two major challenges possess the use of diesel engines; fossil fuel sustainability and the environmental concern on engine emissions. However, diminishing and unreliable petroleum reserves and deteriorating environment have made scientists seek alternative fuels for diesel.

Since the last decades, researchers around the world have been trying to find new alternative fuels that are available and environmentally acceptable [2]. One of the promising alternative fuels considered for diesel engines is biodiesel [3]. Biodiesel is renewable as well as environmentally friendly fuel. It has similar properties to diesel fuel. Addition of fuel additive is one of the possible approaches for reducing the high viscosity problem of biodiesels. The oxygen concentration 
in the combustion chamber can be increased by adding oxygenates to the diesel fuel. Oxygenates like propanol, butanol, pentanol, methoxide ethanol, ethoxy ethanol, diethyl ether, butoxy ethanol dibutyl ether and nitromethane are widely used. Out of all oxygenated additives, nitromethane (NM) has some promising properties.

A number of experimental investigations have been reported with a wide variety of oxygenating additives and biodiesel fuels to improve fuel properties, engine performance, and reduce emissions. Till today, several biodiesel fuels for compression ignition (CI) engines have been investigated. Most investigations show that the use of biodiesel results in lower emissions (except $\mathrm{NO}_{\mathrm{x}}$ ) and better combustion [4]. Increasing brake specific fuel consumption (BSFC) and brake thermal efficiency (BTE) using biodiesel in diesel engines have been reported [5-9], and a decrease of BTE [10, 11]. Also, studies show that CO, HC and PM emissions and exhaust smoke of the engine fueled with biodiesel-diesel blend are lower than that of diesel $[5,7,8]$. Despite the fact that the majority of harmful emissions are mitigated when using biodiesel compared to petroleum diesel, but $\mathrm{NO}_{\mathrm{X}}$ emissions were found higher for biodiesel in many studies [12-14]. Gillani et al. [15] studied the engine performance, combustion, and diesel engine emissions fueled with diesel, Jatropha biodiesel (JBD), Jatropha-butanol blended fuel and Jatropha biodiesel with fumigated butanol. The pure JBD showed a $5 \%$ reduction in BTE and a $17 \%$ increase in BSFC compared to pure diesel combustion. Jatropha-butanol blended fuel showed better efficiency compared to pure Jatropha (by $2 \%$ ). Emissions of $\mathrm{NO}_{\mathrm{X}}$ and UHC reduced when pure Jatropha was used compared to diesel fuel.

Rathore et al. [16] experimentally investigated the performance characteristics of CI engines fueled with diesel, JBD and coconut biodiesel. The diesel blends (B20 - B50) were tested at the fixed compression ratio. They reported that BSFC of diesel fuel was lower than blended fuels while BTE was higher. At all loads, the BSFC and BTE of Jatropha blends reveal the least and greatest among all the blends. Ali and Rind [17] studied Neem and Jatropha blended biodiesel in the CI engine. They reported that CO emission of 10\% Neem biodiesel (NB10) was the least, followed by $10 \%$ Jatropha biodiesel (JB10), compared to pure diesel. Their overall results showed that the engine performance and emission characteristic of NB10 was better compared to other biodiesel blends.

Several researchers investigated the effect of different oxygenated additives (2 ethoxy ethyl acetate, diethyl ether, diphenyl ether, diethelene glycol dimethyl ether and nitromethane) on diesel fuel. Various results of improvement in diesel properties have been obtained by using different additives. Similarly, oxygenate additives were used by different researchers to improve the performance and emissions of diesel engines. Loganathan et al. [18] used dimethyl ether (DME) as an additive to enhance combustion characteristics. They experimentally determined the effect of dimethyl ether (DME) with Jatropha biodiesel in a diesel engine. Jatropha biodiesel dimethyl ether (BDE) blends showed better performance and emission characteristics compared to neat Jatropha biodiesel. The biodiesel 95\% and dimethyl ether 5\% (BDE5), dimethyl ether 10\% (BDE10) and dimethyl ether 15\% (BDE15) were tested in a single-cylinder, direct injection diesel engine. The UHC emissions for the blends were found to be lower than that of the neat jatropha biodiesel. The reduction in UHC was in the order of $42 \%, 36 \%$ and $26 \%$ for BDE5, BDE10 and BDE15, respectively. A similar trend was observed for $\mathrm{CO}$ and $\mathrm{NO}_{\mathrm{X}}$ as well.

Moghaddam and Moghaddam [19] experimentally studied the effect of NM and nitro ethane (NE) as additives on combustion, performance and emission of diesel fuel. The experiment was performed on a water-cooled four cylinders DI diesel engine. They reported that the addition of NM and NE in diesel fuel increased the BTE and reduced exhaust smoke. An average of $35.7 \%$ and $16.2 \%$ smoke generation mitigation were achieved by $10 \%$ addition of NE and NM, respectively. The current research deals briefly with the production of JBD from Indian Jatropha curcas oil. The combustion characteristics, engine performance and emissions of the diesel engine using diesel-biodiesel-NM with different ratios were studied. The combustion characteristics (cylinder pressure, ROHR), performance (BSFC, BTE, EGT) and emissions ( $\mathrm{CO}, \mathrm{CO} 2, \mathrm{NOx}$ and $\mathrm{UHC}$ ) have been studied at a constant speed and varying load conditions without altering the injection times.

\section{MATERIALS AND METHODS}

\section{Biodiesel Production and Test Fuels}

Biodiesel is simply a liquid fuel derived from vegetable oils and fats, which has similar combustion properties to regular petroleum diesel fuel. The most commonly used method for the production of biodiesel is transesterification. Several works on the production of biodiesel by transesterification have been performed and revealed that transesterification is a promising method for fuel production [20-22]. The transesterification process is the reaction of a triglyceride (fat/oil) with an alcohol (like methanol or ethanol) in the presence of a catalyst (typically a strong base such as sodium hydroxide $(\mathrm{NaOH})$ or potassium hydroxide $(\mathrm{KOH})$ to form esters and glycerol [23]. If methanol was used in the chemical reaction, methyl esters are formed, but if ethanol was used, then ethyl esters are formed. In this study the biodiesel production experiment was conducted using a beaker as the reactor. In the first step, Jatropha oil was filtered to remove impurities. Then, the raw oil was heated up to $110^{\circ} \mathrm{C}$ in order to remove the water content of oil; to avoid soap formation. This oil was allowed to cool up to $55^{\circ} \mathrm{C}$. Methanol and $\mathrm{KOH}$ were mixed to form potassium methoxide. A molar ratio of $6: 1$ is normally used in industrial processes to obtain methyl ester yields higher than $98 \%$ by weight because a lower molar ratio required more reaction time. So, methanol with a molar ratio of $(6: 1)$ and $1 \% \mathrm{KOH}$ by weight of oil were mixed and stirred until $\mathrm{KOH}$ dissolved into methanol. Then Jatropha oil was added to the mixture of methanol and $\mathrm{KOH}$ (potassium methoxide). The whole mixture was stirred for 1 hour with the help of a magnetic stirrer at $60{ }^{\circ} \mathrm{C}$ (because the methanol boiling point is at $65^{\circ} \mathrm{C}$ ) during the transesterification process. The mixture was then allowed to settle. The glycerin phase is much denser than the biodiesel phase; therefore it settled down at the bottom. It took more 
than an hour. After separation, methyl ester (biodiesel) contains only $\mathrm{KOH}$ in the form of impurity. $\mathrm{KOH}$ is harmful to diesel engines; therefore, it must be separated from biodiesel. The water washing process was used for removing $\mathrm{KOH}$ from biodiesel. Water (at $55^{\circ} \mathrm{C}$ ) mixed into separated methyl ester and left for settling down. $\mathrm{KOH}$ dissolved in water and separated from biodiesel. Excess water is removed by heating the biodiesel up to $120{ }^{\circ} \mathrm{C}$. Finally, Jatropha methyl ester formed as a light yellow liquid. Different fuel mixture has been tested and compared with baseline diesel in this study: 10\% JBD-diesel (B10), 10\% JBD- 1\% NM-diesel (B10NM1), 10\% JBD- 3\% NM-diesel (B10NM3), 20\% JBDdiesel (B20), 20\% JBD- 1\% NM-diesel (B20NM1) and 20\% JBD- 3\% NM-diesel (B20NM3). The major properties of the tested fuels are listed in Table 1 [19, 24- 26].

Table 1. Properties of the diesel, JBD and NM.

\begin{tabular}{|c|c|c|c|c|c|c|}
\hline Properties & Biodiesel test method & Limits & Diesel ASTM D975 & Diesel & JBD & NM \\
\hline Lower heating value $(\mathrm{MJ} / \mathrm{kg})$ & - & - & - & 4242 & 38.2 & 11.4 \\
\hline Density $\left(\mathrm{kgm}^{-3}\right)$ at $15^{\circ} \mathrm{C}$ & ISO 3675/P32 & $860 \sim 900$ & $\sim 835$ & 830 & 880 & 1138 \\
\hline Cetane number & ISO 5156/P9 & $51 \mathrm{~min}$ & $40-55$ & 49 & 51 & - \\
\hline Acid value (mg KOH/g) & EN14104/P1 & $0.5 \max$ & - & - & 0.42 & - \\
\hline Viscosity $\left(\mathrm{mm}^{2} \mathrm{~s}^{-1}\right)$ & ISO3104/P25 & $2.5 \sim 6.0$ & $1.3-4.1$ & 2.45 & 4.62 & 4.1 \\
\hline Flash point $\left({ }^{\circ} \mathrm{C}\right)$ & ISO3679/P21 & $120 \mathrm{~min}$ & $60-80$ & 75 & 185 & 34 \\
\hline Cloud point $\left({ }^{\circ} \mathrm{C}\right)$ & D2500 & $-3 \sim 12$ & $-15 \sim 5$ & -15 & 1 & -25 \\
\hline Pour point $\left({ }^{\circ} \mathrm{C}\right)$ & ISO 3016 & $-15 \sim 10$ & $-35 \sim-15$ & -20 & -2 & -28.6 \\
\hline Iodin value $(\mathrm{g} \mathrm{I} / 100 \mathrm{~g})$ & EN14111 & $120 \max$ & - & - & 117 & - \\
\hline
\end{tabular}

The test was performed on a single-cylinder four-stroke water-cooled direct injection stationary diesel engine. The schematic diagram of the experimental setup and engine specifications are shown in Figure 1 and Table 2. The engine had a bore and stroke of 87.5 and $110 \mathrm{~mm}$, respectively, with a displacement volume of $661 \mathrm{cc}$ and a compression ratio of 17.5:1. In-cylinder pressure was measured by using a piezoelectric type pressure transducer mounted on the cylinder head. A thermocouple type temperature sensor was used to measure the exhaust gas temperature. The five gas analyser (AIRSON OM - 1100) based on a single beam non-dispersive infrared (NDIR) measurement technology was used for emission measurement.

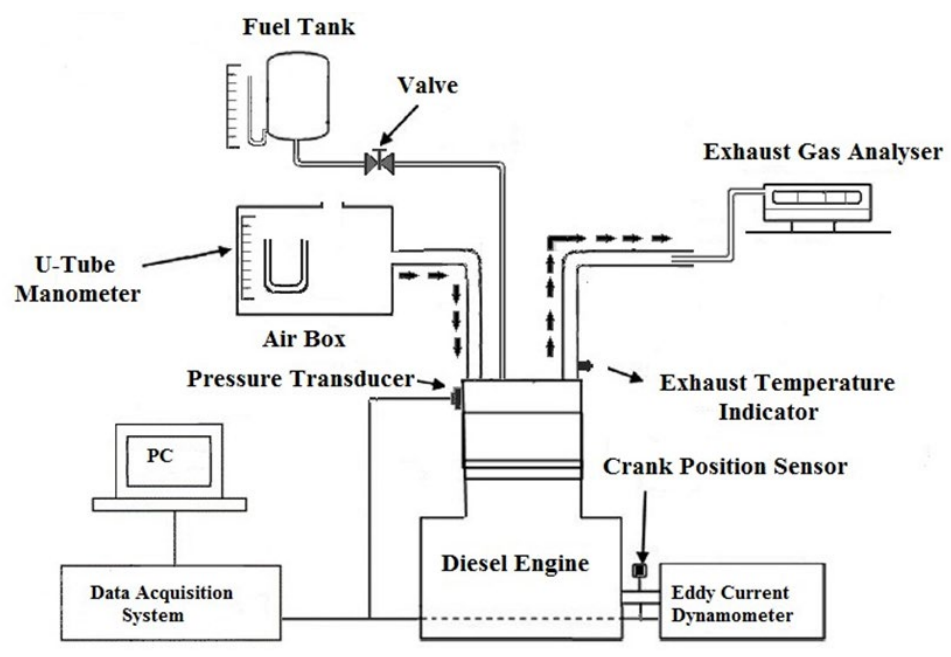

Figure 1. Schematic diagram of the experimental setup.

Table 2. Engine specifications.

\begin{tabular}{lc}
\hline Manufacturer & KIRLOSKAR AVL \\
\hline Type & vertical, four-stroke diesel \\
Number of cylinder & One \\
Bore & $87.5 \mathrm{~mm}$ \\
Stroke & $110 \mathrm{~mm}$ \\
Displacement Volume & $661 \mathrm{cc}$ \\
Compression Ratio & $17.5: 1$ \\
Maximum Power & $5.2 \mathrm{~kW}$ \\
Mode of injection & DI \\
Speed & $1500 \mathrm{rpm}$ \\
Dynamometer & Eddy current dynamometer \\
Cooling system & water \\
\hline
\end{tabular}


The engine was operated with pure diesel and continued to run for 5 minutes at a no-load condition and constant speed to warm up and attain steady-state conditions before the experiment was conducted. The engine was stabilised before data were measured. The test conditions were set for different loads. During the tests with blended fuels, the engine was started with pure diesel until it was warmed up, and then fuel was switched to various diesel-biodiesel blends. After completing the engine tests run with blended fuels, the engine was always switched back to diesel mode and the engine was allowed to run for a few minutes to clear fuel lines and stabilise. All measurements were repeated five times, and the average values are presented here.

\section{RESULTS AND DISCUSSION}

Diesel, JBD, NM and their blends were used separately as a fuel in this experimental investigation without any engine modifications. Initially, the engine was running with pure conventional diesel, and the engine's operating characteristics were recorded as the baseline data. Subsequently, the engine was running using a blend of diesel- biodiesel with and without additive in varying concentrations. The time of injection and engine speed were set at $23^{\circ} \mathrm{bTDC}$ and $1500 \mathrm{rpm}$ and kept the same during all tests. For all sets of observation, several parameters such as cylinder pressure, HRR, BTE, BSFC, EGT and engine emissions are plotted and discussed in the following sections.

\section{Engine Performance}

\section{Brake specific fuel consumption}

Brake specific fuel consumption (BSFC) is a measure of how efficiently a given amount of fuel is converted into a specific amount of horsepower. Variations of BSFC with engine loads for all test fuels are shown in Figure 2 (a) and 2(b). It can be seen that the BSFC is higher at the lower engine loads and gradually decreases with an increase in load for all blended fuels [27-31]. This could be caused by increasing air pressure at higher loads [32]. Also, results showed that increasing the percentage of JBD and NM in blends result in increasing BSFC [33, 34]; as the BSFC was calculated on a weight basis, higher density of JBD and NM resulted in higher values for BSFC. More biodiesel fuel mass is delivering to the engine for the same power output because of the higher density of biodiesel compare to diesel fuel [35]. The higher BSFC of JBD and NM can also be explained by their lower heating values in comparison with diesel fuel [36]. It is also observed that diesel fuel had the highest fuel economy, whereby B20NM3 recorded the least fuel economy at all engine loads. Such behaviour has been reported by other researchers [37- 39]. The BSFC for B20NM3 was the highest among all the fuels tested (up to $3.2 \%$ at full engine load).

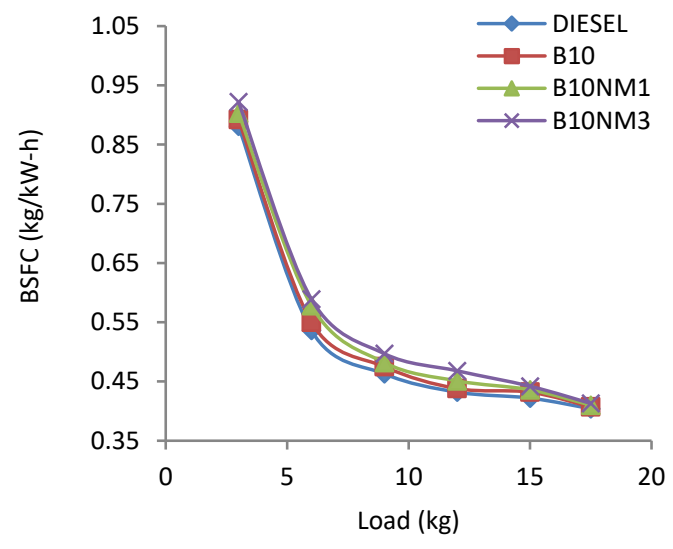

(a)

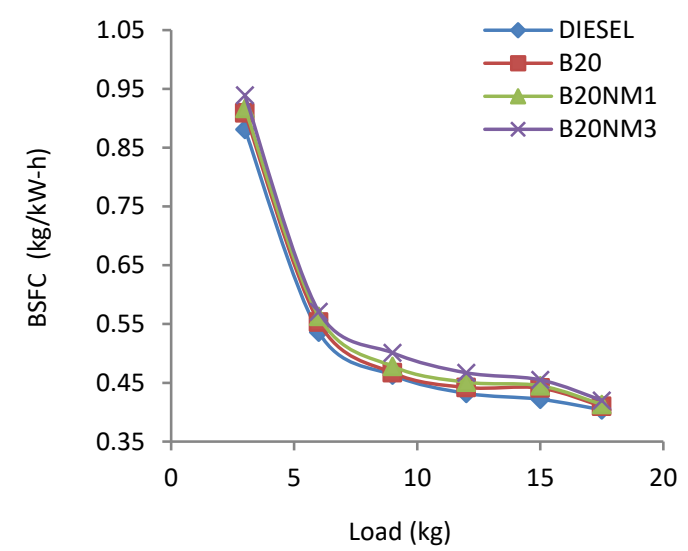

(b)

Figure 2. BSFC vs Load for (a) B10 and (b) B20, with and without additives.

\section{Brake thermal efficiency}

Brake thermal efficiency (BTE) is defined as the break power of a heat engine as a function of the thermal input from the fuel. Figure 3(a) and 3(b) illustrate the change in the BTE as a function of load measured. The BTE of diesel is lower than those of blended fuels. A higher cetane number and higher oxygen content of blended fuels promote combustion, and these improve BTE. The BTE increased with an increase in load for all test fuels. This was achieved due to the reduction of heat loss at higher engine load [34]. Pure diesel recorded the lowest thermal efficiency at a higher engine load. However, differences became clearer at full engine load. All blends show slightly lower brake thermal efficiency at lower engine loads due to higher viscosity and poor atomisation, and unfavourable conditions in the cylinder. Higher thermal efficiency of blended fuels at higher loads may be explained as biodiesel and nitromethane contain high oxygen content, which results in better combustion in the engine [37, 39, 40-42] and higher heat of evaporation for complete combustion [43]. At full load condition, the greatest BTE was achieved for B20NM3, which is $11.73 \%$ higher than that of diesel fuel. It is evident from the plots that the BTE increases with an increase in nitromethane concentration as well as biodiesel concentration for all engine loads. However, results from [27] and [29] show that the BTE of biodiesel blends is higher up to $30 \%$ biodiesel blend compared to pure diesel. But further increase shows gradual reduction of BTE for all blends. 


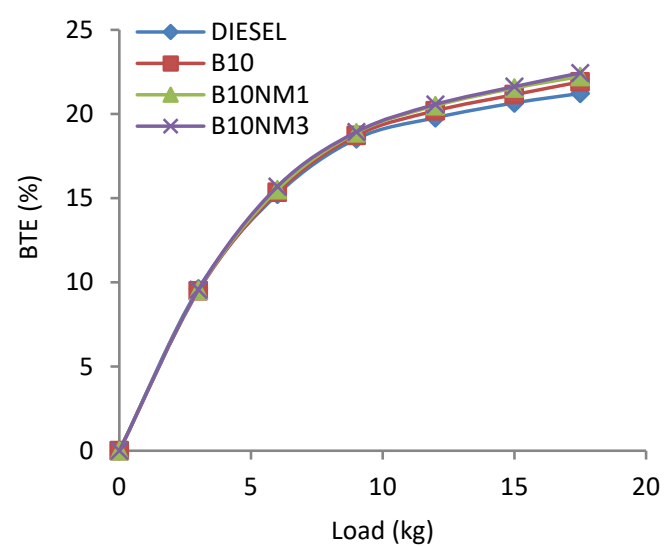

(a)

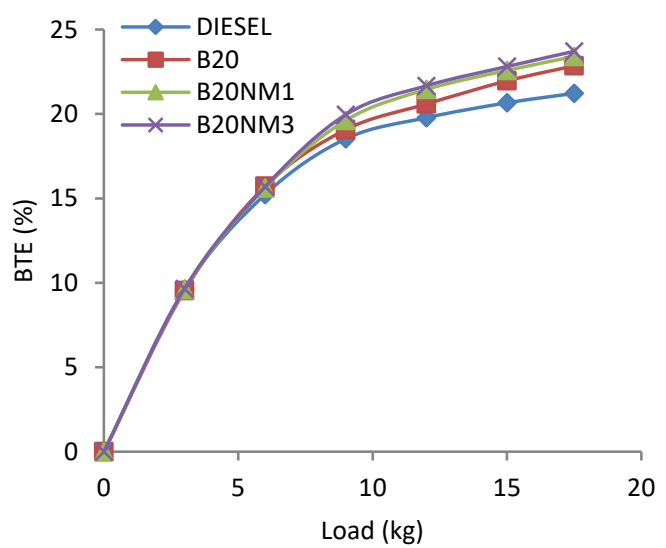

(b)

Figure 3. BTE vs engine loads for (a) B10 and (b) B20, with and without additives.

\section{Exhaust gas temperature}

Figure 4 (a) and 4(b) show the variation of the exhaust gas temperature (EGT) with respect to engine loads. It is clear from plots that EGT increases with loads for all the fuel blends. This increase in EGT with loads is obvious from the simple fact that more amount of fuel is required in the engine to generate that extra power needed to take up the additional loading. The EGT of diesel fuel is lower than blends and it increases with an increase of JBD and NM concentration in blends at all loading conditions. This is because that combustion efficiency improves with an increase in biodiesel concentration. Generally, a lower EGT indicates better combustion and less heat loss, which means the heat generated from the combustion of fuel is efficiently converted to the work. However, the higher EGT of blends may be attributed to their higher oxygen content and cetane number, which promotes combustion and shorter ignition delay, respectively. The addition of NM in blended fuels further improves the combustion, resulting in higher exhaust temperature than pure diesel. An earlier burning in the case of biodiesel blends due to a shorter premixed combustion period (due to higher $\mathrm{CN}$ of biodiesel) results in higher EGT [11]. The lowest and highest values of EGT $\left(712.5^{\circ} \mathrm{C}\right.$ and $\left.767{ }^{\circ} \mathrm{C}\right)$ were recorded for diesel and B20NM3, respectively, at full load conditions.

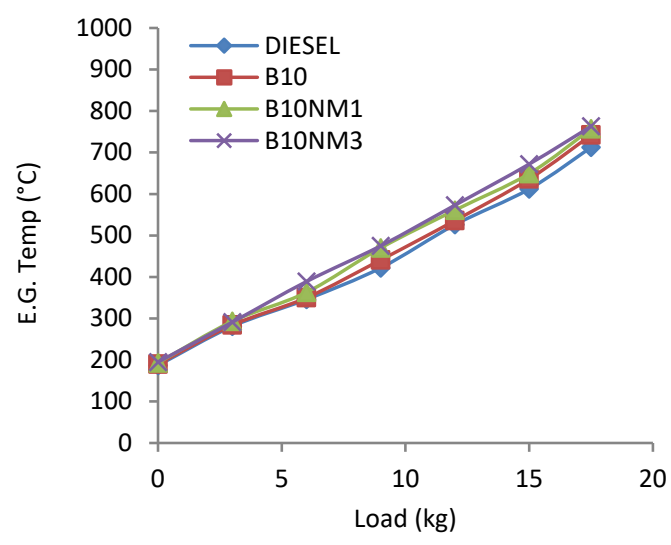

(a)

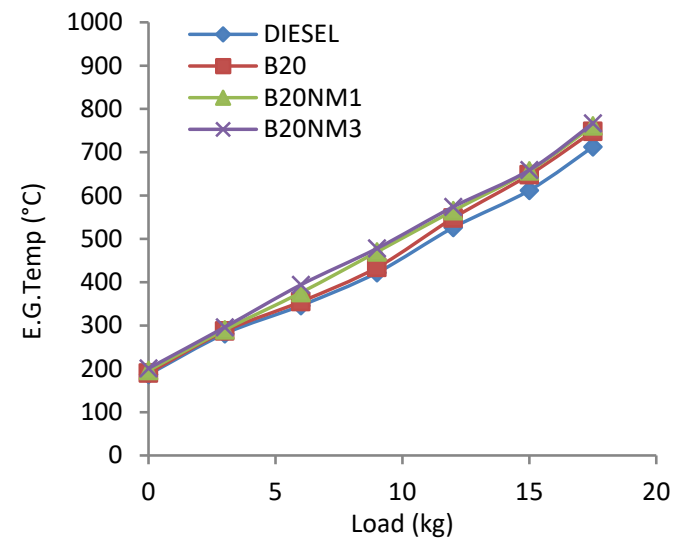

(b)

Figure 4. EGT vs Load for (a) B10 and (b) B20, with and without additives.

\section{Engine Emissions}

\section{Carbon monoxide}

Generally, carbon monoxide (CO) emissions are affected by the fuel type, injection timing, injection pressure, engine load and engine speed [7]. Figure 5(a) and 5(b) depict the test results of CO emission for various engine loads and blends. The first observation that can be noticed is that the trend of $\mathrm{CO}$ emission from the engine using different fuels is similar to each other. The $\mathrm{CO}$ emission is low when the engine runs at low and medium loads but tends to be higher at high engine loads. Without load, the CO emission of the fuel blends is 1.6-15\% higher than diesel fuel. It can be because mixed fuels with higher density, viscosity and molecular weight are responsible for poor atomisation at the low loads and hence the higher concentration of CO. Higher the engine load, the richer fuel-air mixture is burned, and thus more $\mathrm{CO}$ is produced [44]. At full engine load, the CO emission of all the test fuel blends is 18.6-28.9\% lower than that of diesel. The main reason for the low $\mathrm{CO}$ concentration at high engine loads from the combustion of the blended fuels is the oxygen content of biodiesel and NM, which makes the combustion of blends more complete. The remarkable higher oxygen content of NM (52\%) compare to diesel and biodiesel results in lower $\mathrm{CO}$ emission. The results for the $\mathrm{CO}$ emission are 
consistent with most of the literature [37, 340, 41, 45]. At full load condition, the CO emission of B20NM3 is $28.91 \%$ lower than that of diesel which is highest of the all tested fuels.

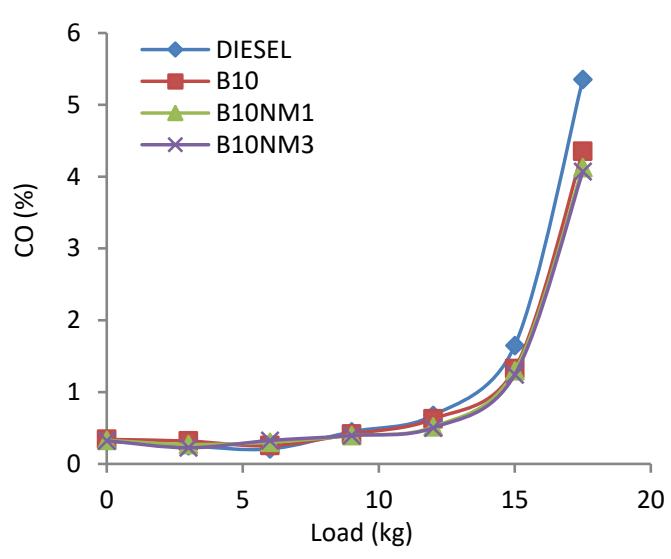

(a)

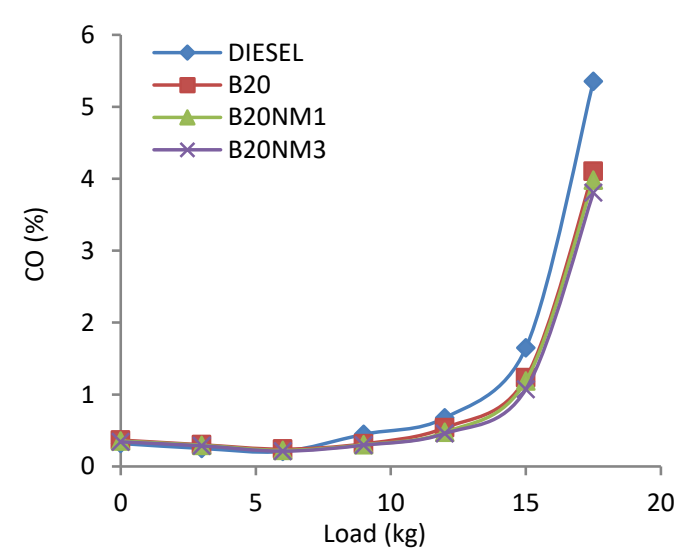

(b)

Figure 5. CO emission vs load for (a) B10 and (b) B20, with and without additives.

\section{Carbon dioxide}

The concentration changes of carbon dioxide $\left(\mathrm{CO}_{2}\right)$ with respect to engine loads are illustrated in Figure 6(a) and 6(b). It can be observed that $\mathrm{CO}_{2}$ emissions increased with increased engine loads as well as biodiesel and additive concentrations in fuel blends. This is due to the burning of more amount of fuel at high load conditions and more efficient combustion of test fuels; because the JBD and NM contain more oxygen than pure diesel. Also, higher loads provide a better condition for combustion (in terms of temperature and pressure). In regards to $\mathrm{CO}-\mathrm{CO}_{2}$ conversion mechanism, it can be explained that the higher oxygen content of JBD and NM can accelerate the reaction rate of the following $\mathrm{CO}_{2}$ production mechanism $\left(\mathrm{CO}+\mathrm{O}_{2}=\mathrm{CO}_{2}+\mathrm{O}\right)$ and resulted in more $\mathrm{CO}_{2}$ emissions. More amount of $\mathrm{CO}_{2}$ in exhaust emission is an indication of the complete combustion of fuel. At lower loads, test fuels show an insignificant difference in $\mathrm{CO}_{2}$ levels compared to pure diesel, but at higher loads, these differences increase gradually. It is observed that B20NM3 blend produced higher $\mathrm{CO}_{2}$ emissions throughout all blends. The per cent changes (increase) in $\mathrm{CO}_{2}$ emissions at full-load operating conditions for B10 and B20NM3 were obtained $4.38 \%$ and $10.52 \%$, which are the lowest and highest among all test fuels, respectively.

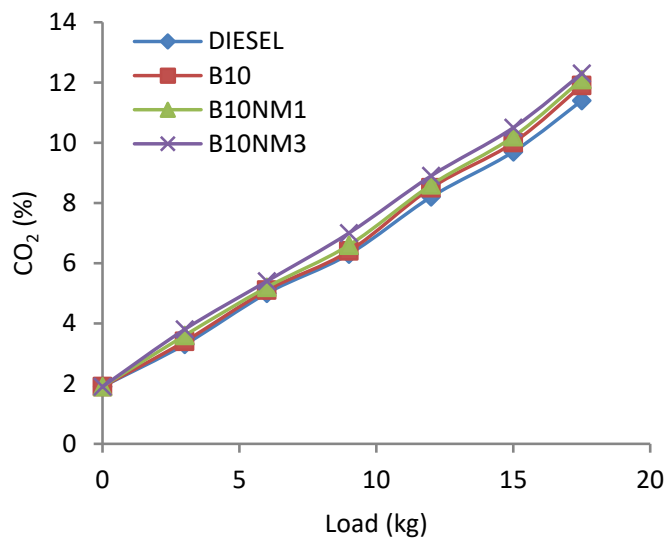

(a)

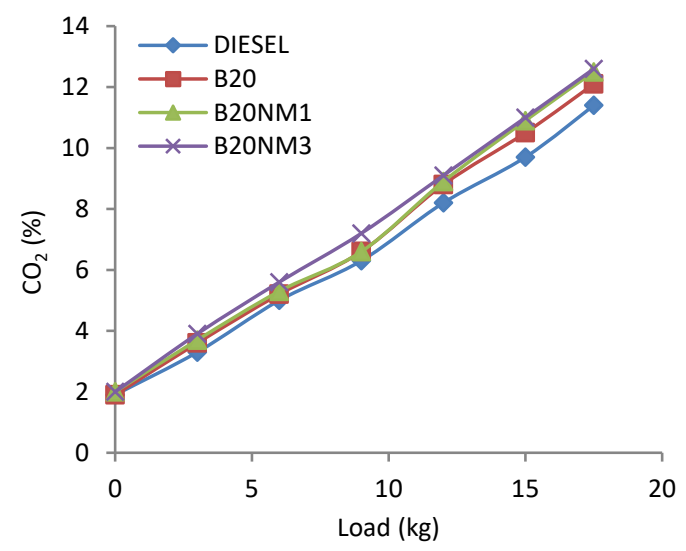

(b)

Figure 6. $\mathrm{CO}_{2}$ emission vs load for (a) B10 and (b) B20, with and without additives.

\section{Unburnt hydrocarbon}

Hydrocarbon emission is an indicator of combustion efficiency. The variations of unburnt hydrocarbon (UHC) emission with loads for different fuels are illustrated in Figure 7(a) and 7(b). The UHC emission increases with increasing load, while UHC emission decreases with increasing JBD and NM percentages in the blends. This decline in UHC concentration may be due to the oxygen content in JBD and NM, which improves the quality of combustion. The UHC emission trend for blended fuels and diesel is almost the same when operating at different loads. However, at a high load, a greater amount of fuel is injected per cycle and this leads to making over-rich mixture in the local region, causing a significant increase in UHC emission. Also, high cylinder gas temperature can enhance the HC oxidation results in mitigation of UHC formation. Further, it can be seen that, UHC emission of blends is lower than that of diesel and decreases with increasing the proportion of JBD and NM in blends, especially at high load. It can be explained that the addition of biodiesel and NM into diesel improves the content of oxygen which enhances combustion. The main 
components of biodiesel are fatty acid methyl ester. This causes complete combustion and UHC mitigation [46, 47]. The existence of oxygen in biodiesel and NM increases the combustion efficiency. The B20NM3 blend produced the lowest unburned fuel emission compared to all test fuels. At full load condition, the B20NM3 blend emitted 24.24\% lower unburned fuel emission than that of diesel fuel.

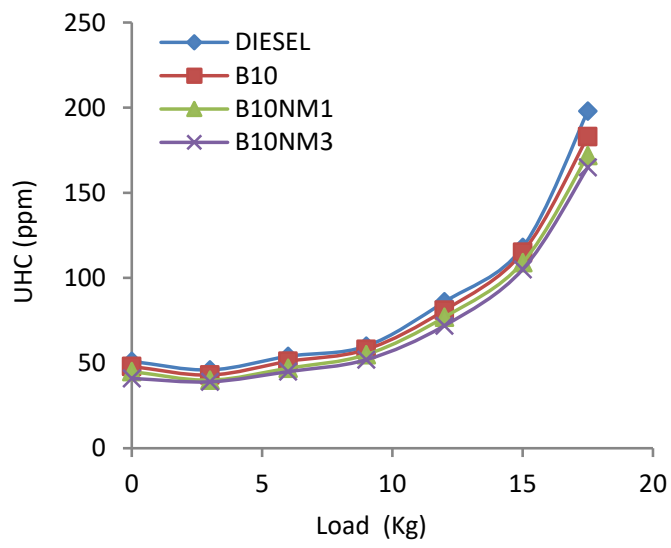

(a)

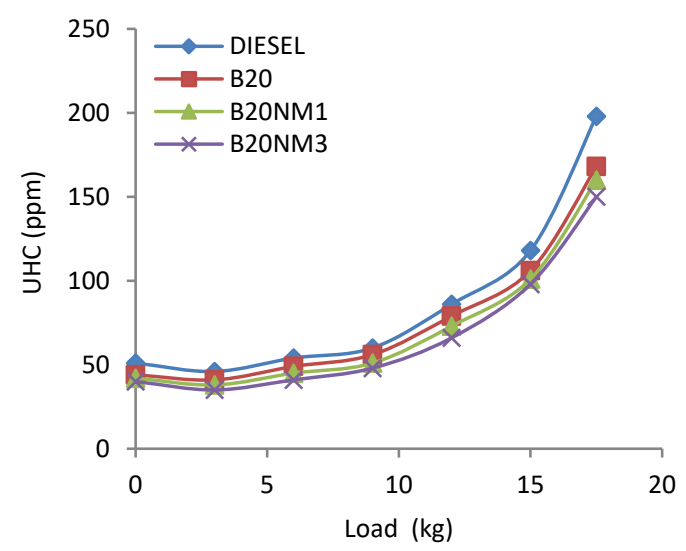

(b)

Figure7. UHC emission vs load for (a) B10 and (b) B20, with and without additives.

\section{Nitrogen oxides}

Figure 8(a) and 8(b) show the variations of nitrogen oxides $\left(\mathrm{NO}_{\mathrm{x}}\right)$ emissions in the exhaust with respect to engine loads. $\mathrm{NO}_{\mathrm{x}}$ formation increases as the load increases [23, 27], which is the result of higher combustion temperature due to higher engine load. Researchers have proposed that the oxygen content of biodiesel is an important factor in $\mathrm{NO}_{\mathrm{x}}$ formation because it increases the local temperature $[12,46]$. Considering the $\mathrm{NM}$ oxidation mechanism $\left(4 \mathrm{CH}_{3} \mathrm{NO}_{2}+3 \mathrm{O}_{2}\right.$ $=4 \mathrm{CO}_{2}+6 \mathrm{H}_{2} \mathrm{O}+2 \mathrm{~N}_{2}$ ), it can be seen that the $\mathrm{NM}$ oxidation reaction also produces nitrogen gas during the combustion, which increases $\mathrm{NO}_{\mathrm{x}}$ concentration in exhaust emission. It can be seen that the $\mathrm{NO}_{\mathrm{x}}$ emissions increased with the increase of the engine loads as well as concentrations of JBD and NM in blends [47-49]. In summary, the high combustion temperature (due to a higher load) and the oxygen content of JBD and NM are responsible for increased NOx formation. The NOx emissions of all fuel blends are 6.97-14.31\% higher than that of pure diesel at full load. At full load condition, B20NM3 fuel blend recorded the highest change in $\mathrm{NO}_{\mathrm{x}}$ while B10 recorded the lowest, which are 14.31\% and 6.97\%, respectively.

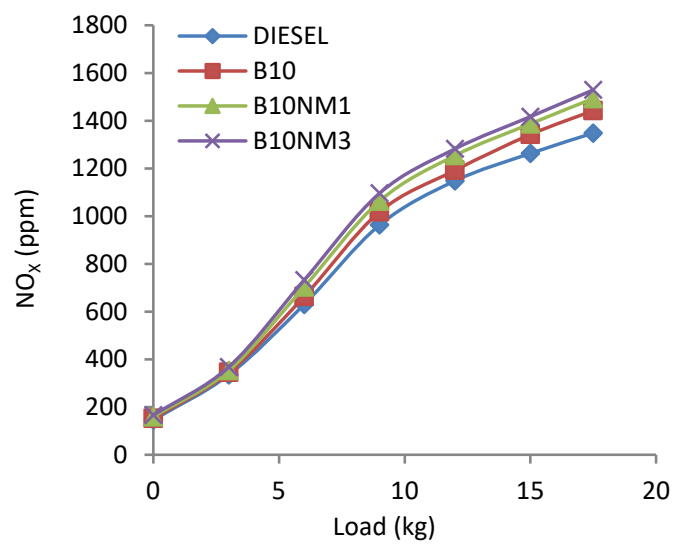

(a)

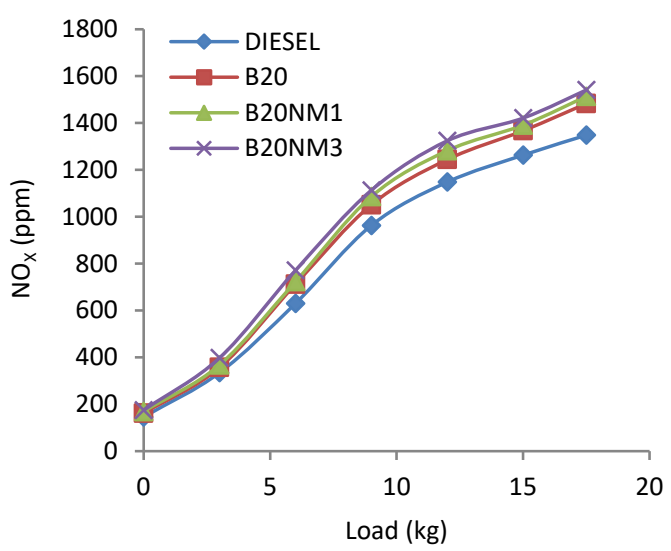

(b)

Figure 8. $\mathrm{NO}_{\mathrm{x}}$ emission vs load for (a) B10 and (b) B20, with and without additives.

\section{Combustion Characteristics}

\section{Cylinder pressure and rate of heat release}

Combustion in diesel engines takes place in four distinct phases. The overall diesel combustion process described in Heywood [50] can be summarised here by identifying a typical heat-release-rate diagram of a direct injection engine with one injection per engine cycle, as shown in Figure 9. The variations of cylinder pressure with crank angle for diesel, blended diesel with and without additive are shown in Figure 10(a) and 10(b) at full load conditions. It is clear that the peak cylinder pressure decreases with the increase of JBD concentration, whereas it increases with the increase of NM concentration in the blends. This behaviour has been described in a similar study [40]. It is because the delay period for JBD and NM is shorter and the combustion begins a few degrees earlier compared to diesel, hence the earlier peaks for the blended fuels. However, the combustion process of all the blended fuels is similar, consisting of a phase of premixed 
combustion followed by a phase of diffusion combustion. The premixed combustion phase is controlled by the ignition delay period, air-fuel mixture and spraying condition of the injected fuel. Therefore, the viscosity and volatility of the fuel have a very important role in increasing the atomisation rate and improving air-fuel mixing formation. Because of the high viscosity and low volatility of JBD and NM, blends obtained lower cylinder peak pressure with respect to pure diesel. The peak pressure values at full load condition for all test fuels were obtained from Figure 10(a) and 10(b) and are presented as a bar diagram in Figure 11. The percentage reduction in peak cylinder pressure at full load condition for B10NM3 is $1.92 \%$ which is the lowest, whereas for B20, it reaches $6.74 \%$, which is the highest among all test fuels. This certainly shows the role of NM as an additive.

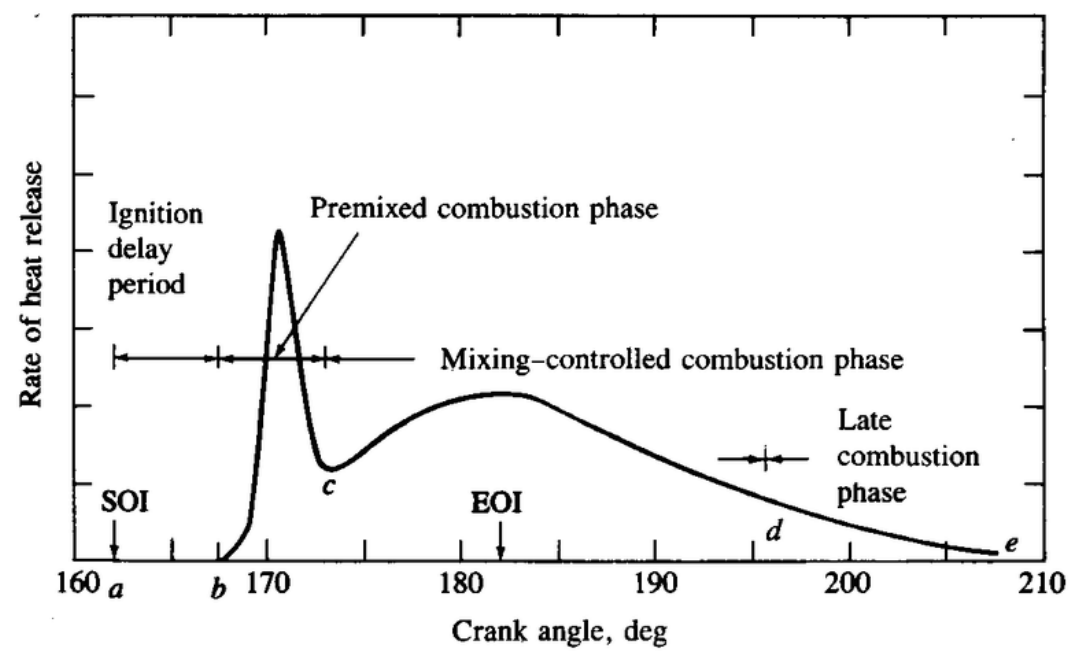

Figure 9. Typical heat release rate diagram of direct injection engine identifying diesel combustion phases [50].

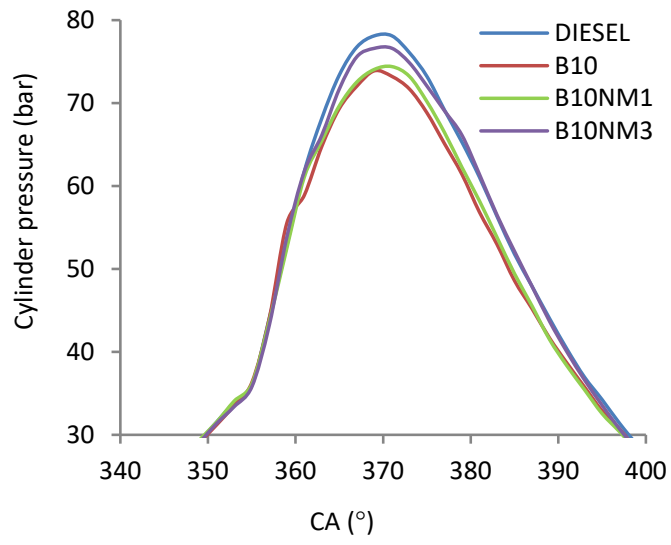

(a)

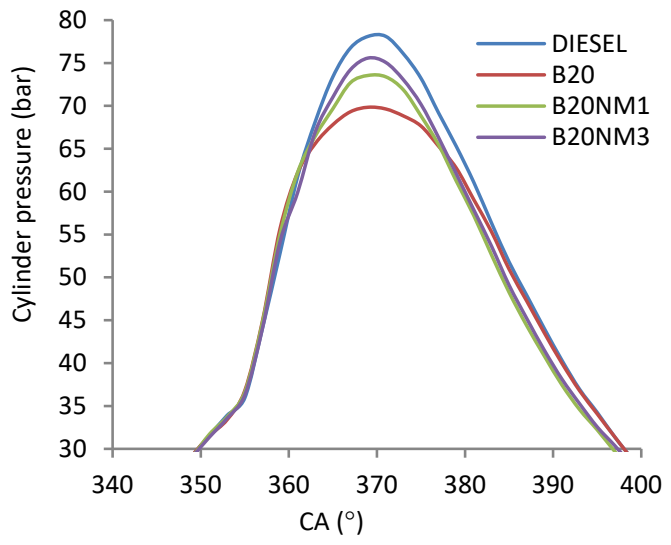

(b)

Figure 10. Cylinder pressure at full load for (a) B10 and (b) B20, with and without additives.

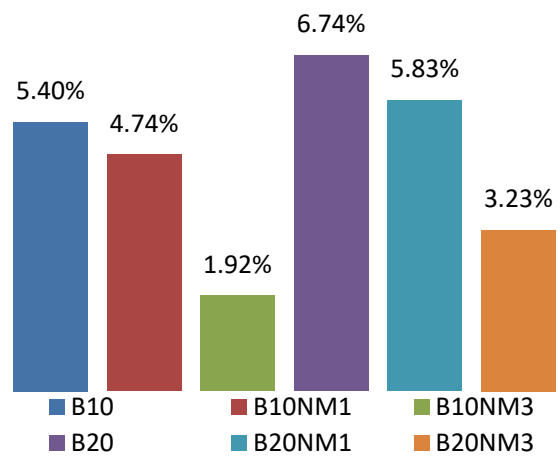

Figure 11. Percentage reduction of peak cylinder pressure at full load with respect to diesel.

A recognised method for analysing combustion characteristics of fuel in the combustion chamber is the heat release rate (HRR). The heat release rate $(d Q / d \theta)$ was calculated after rearranging and simplification in the form of Eq. (1), which was derived from the first law of thermodynamics [51]. 


$$
d Q / d \theta=\frac{1}{(\gamma-1)}\left[\gamma P \frac{d V}{d \theta}+V \frac{d P}{d \theta}\right]
$$

Where, $\gamma$ is the ratio of specific heats, $\theta$ is the crank angle, $P$ is cylinder gas pressure, and $V$ is cylinder volume.

Figure 12(a) and 12(b) show the variation of HRR at full engine load. In these plots, the maximum HRR of blended fuels is lower than that of diesel because of the shorter ignition delay and subsequently shorter premixed combustion phase for JBD and NM blends. Because of the shorter ignition delay, maximum HRR occurs earlier for fuel blends in comparison with pure diesel. A longer ignition delay of diesel fuel causes more rapid and higher pressure rise. However, the HRR during the diffusion combustion phase for test fuels is slightly higher than that of diesel. This can be due to the higher oxygen content of blends. Higher oxygen contents cause complete combustion of the fuel that is left over during the main combustion phase and continue to burn in the late combustion phase [7, 35, 37]. The percentage reduction in maximum HRR at full engine load condition for B10NM3 is 5.59\% which is the lowest, and for B20 recorded at $16.05 \%$ which is the highest among all test fuels, as shown in Figure 13.

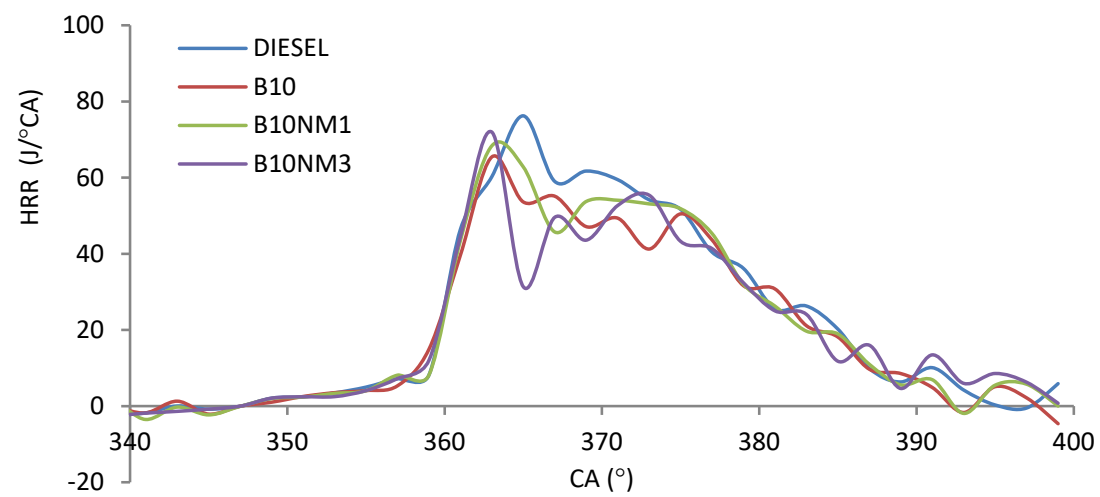

(a)

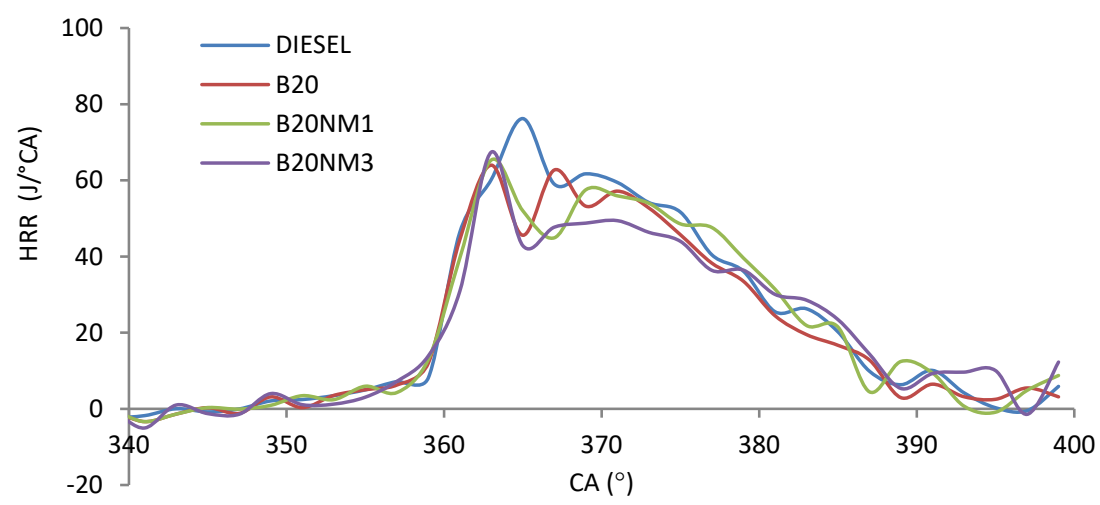

(b)

Figure 12. HRR at full engine loads for (a) B10 and (b) B20, with and without additives.

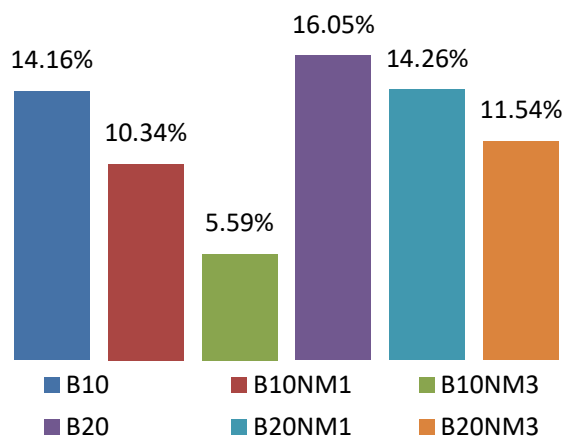

Figure 13. Percentage reduction in maximum HRR at full load with respect to diesel.

\section{CONCLUSION}

The current experimental work is presented to show the biodiesel production with transesterification method in laboratory scale and to investigate the combustion, performance and emission characteristics of diesel engine fueled with pure diesel, biodiesel derived from Indian Jatropha oil and NM as an additive to diesel-biodiesel blends. Experiments 
were performed using a direct injection single cylinder diesel engine. Several blends were tested and compared with diesel fuel. The following key findings are drawn from results:

i. Jatropha biodiesel with base catalysed transesterification method was prepared and tested in diesel engine.

ii. The BSFC and EGT of blends were found to be increased by $1.24 \%$ to $6.58 \%$ and $4.18 \%$ to $7.68 \%$, respectively as compared with pure diesel at different engine loads.

iii. BTE was found to be increased by $3.25 \%$ to $11.73 \%$ with an increase in JBD and NM concentration in the fuel blends. Among the all fuel blends tested, B20NM3 had highest BSFC and EGT as well as BTE at full engine load. With an increase in engine load, the BSFC decreased, whereas BTE increased for all the fuels tested.

iv. The $\mathrm{CO}$ and UHC emissions of the diesel engine when operated with fuel blends were mitigated by $18.6 \%$ to $28.9 \%$ and $7.5 \%$ to $24.26 \%$ respectively as compared with pure diesel, whereas $\mathrm{NOx}$ and $\mathrm{CO}_{2}$ emissions increased by $6.9 \%$ to $14.3 \%$ and $4.3 \%$ to $10.5 \%$, respectively. It was found that the engine load has not remarkable influence on $\mathrm{CO}$ and $\mathrm{UHC}$ emissions but considerable effect on $\mathrm{NO}_{\mathrm{x}}$ and $\mathrm{CO}_{2}$ emissions were observed.

v. The peak cylinder pressure decreased with the increase of JBD concentration whereas it increased with the increase of NM concentration in the blends. Because of the high viscosity and low volatility of JBD and NM, blended fuels obtained lower cylinder peak pressure with respect to pure diesel. Also, JBD and NM addition caused the shorter ID and subsequently short premixed combustion phase resulted in lower and earlier maximum HRR.

In the current investigation, it has confirmed that Jatropha oil may be used as resource to obtain biodiesel (in particular India). Transesterification is a promising method for the production of biodiesel in large scale. Based on the overall results, B20NM3 was found as a favorable fuel for diesel engine in this study. Based on the results of the engine tests, it has been established that the NM can be used as an effective additive and the JBD can be substituted for diesel without any modification of the engine.

\section{REFERENCES}

[1] Fernando S, Hall C, Jha S. $\mathrm{NO}_{\mathrm{x}}$ reduction from biodiesel fuels. Energy \& Fuels 2006; 20: 376-82.

[2] Liaquat AM, Kalam MA, Masjuki HH, Jayed MH. Potential emission reduction in road transport sector using biofuel in developing countries. Atmospheric Environment 2010;44:3869-7387.

[3] Mufijur M, Masjuki HH, Kalam MA, et al. Prospects of biodiesel from Jatropha in Malaysia. Renewable and Sustainable Energy Reviews 2012;16: 5007-5020.

[4] Spataru A, Romig C. Emissions and engine performance from blends of soya and canoa methyle ester with ARB\#2 diesel in a DCC6V92TAMUI Engine. SAE Technical Paper: 952388; 1995.

[5] Lim C, Lee J, Hong J, et al. Evaluation of regulated and unregulated emissions from a diesel powered vehicle fueled with diesel/biodiesel blends in Korea. Energy 2014; 77: 533-541.

[6] Hossain AK, Ouadi M, Siddiqui SU, et al. Experimental investigation of performance, emission and combustion characteristics of an indirect injection multi-cylinder CI engine fuelled by blends of de-inking sludge pyrolysis oil with biodiesel. Fuel 2013, 105:135-142.

[7] Ozener O, Yuksek L, Ergenc AT, Ozkan M, Effects of soya bean biodiesel on a DI diesel engine performance, emission and combustion characteristics. Fuel 2014; 115:875-883.

[8] Man XJ, Cheung CS, Ning Z, et al. Influence of engine load and speed on regulated and unregulated emissions of a diesel engine fueled with diesel fuel blended with waste cooking oil biodiesel. Fuel 2016; 180: 41-49.

[9] Sharanabasappa S, Sangshetty K, Ramesha D. Performance and emission parameters of compression-ignition (CI) engine fuelled with waste or used temple oil biodiesel at blends. International Journal of Applied Science - Research and Review 2019; 5(4): 18.

[10] Raheman H, Ghadge SV. Performance of compression ignition engine with mahua (Madhuca indica) biodiesel. Fuel 2007;86: 2568-73.

[11] Hamdeh NHA, Alnefaie KA. A Comparative study of almond biodiesel-diesel blends for diesel engine in terms of performance and emissions. The Journal of Biomedical Research 2015; 2015: 529808.

[12] Zhihao M, Xiaoyu Z, Junfa D, et al. Study on emissions of a DI diesel engine fuelled with Pistacia chinensis bunge seed biodieseldiesel blends. Procedia Environmental Sciences 2011; 11: 1078-1083.

[13] Ozcanli M, Keskin A, Aydın K. Biodiesel production from Terebinth (Pistacia terebinth hus) oil and its usage in diesel engine. International Journal of Green Energy 2011; 8: 518- 528.

[14] Wu G, Cong JG, Jung NCh. A comprehensive review of the application characteristics of biodiesel blends in diesel engines. Applied Sciences 2020; 10(22): 8015.

[15] Gillani SE, Ikhlaq M, Khan MU, et al. Effects of butanol blending and fumigation with Jatropha biodiesel on combustion, performance, and emissions of diesel engine. International Journal of Environmental Science and Technology 2021; 18: 819-834.

[16] Rathore Y, Ramchandani D, Pandey RK. Experimental investigation of performance characteristics of compression-ignition engine with biodiesel blends of Jatropha oil \& coconut oil at fixed compression ratio. Heliyon 2019; 5: e02717.

[17] Mehmood A, Saqib JR. Engine performance and emission analysis using Neem and Jatropha blended biodiesel, La Granja: Revista de Ciencias de la Vida 2020; 32(2): 19-29. 
[18] Loganathan M, Anbarasu A, Velmurugan A. Emission characteristics of jatropha dimethyl ether fuel blends on a DI diesel engine. International Journal of Scientific and Technology Research 2012; 1: 28-32.

[19] Mojtaba SM, Abdolsamad ZM. Performance and exhaust emission characteristics of a CI engine fueled with diesel nitrogenated additives. Chemical Engineering Research and Design 2014; 92: 720- 726.

[20] Lin L, Ying D, Chaitep S, Vittayapadung S. Biodiesel production from crude rice bran oil and properties as fuel. Applied Energy 2009; 86: 681-688.

[21] Albuquerque MCG, Machado YL, Torres AEB, et al. Properties of biodiesel oils formulated using different biomass sources and their blends. Renewable Energy 2009; 34: 857-859.

[22] Agarwal D, Kumar L, Agarwal AK. Performance evaluation of a vegetable oil fuelled compression ignition engine. Renewable Energy 2008; 33:1147-1156.

[23] Peterson CL, Feldman M, Korus R, Auld DL. Batch type transesterification process for winter rape oil. Applied Engineering in Agriculture 1991; 7: 711-716.

[24] Ramos MJ, Fernandez CM, Casas A, et al. Influence of fatty acid composition of raw materials on biodiesel properties. Bio resource Technology 2009: 100, 261-268.

[25] Yanfeng G, Shenghua L, Hejun G, et al. A new diesel oxygenate additive and its effects on engine combustion and emissions, Applied Thermal Engineering 2007; 27: 202-207.

[26] Graboski M S, McCornic RL. Combustion of fat and vegetable-oil revived fuels in diesel engines. Progress in Energy and Combustion Science 1998; 24: 125-164.

[27] Abu Saleh A, Sarfaraj K, Tofajjal HC, Sinin H. Biodiesel from jatropha curcas Linnaeus and its performance as blends in diesel engine. In: Proceedings of the International Conference on Mechanical Engineering 2011 (ICME2011), Dhaka, Bangladesh; 1820 December, 2011.

[28] Shi X, Yu Y, He H, et al. Emission characteristics using methyl soyate- ethanol-diesel fuel blends on a diesel engine. Fuel 2005;84:1543-1549.

[29] Forson E, Oduro K, Hammond-Donkoh E. Technical note, performance of jatropha oil blends in a diesel engine. Renewable Energy 2004; 29: 1135-1145.

[30] Murillo S, Miguez JL, Porteiro J, et al. Performance and exhaust emissions in the use of biodiesel in outboard diesel engines. Fuel 2007;86: 1765-1771.

[31] Hanumantha Y, Rao V, Voleti RS, et al. use of jatropha oil methyl ester and its blends as an alternative fuel in diesel engine. Journal of the Brazilian Society of Mechanical Sciences and Engineering 2009; 31: 253- 260.

[32] Maina P. Investigation of fuel properties and engine analysis of Jatropha biodiesel of Kenyan origin. Journal of Energy in Southern Africa 2014; 25: 107-116.

[33] Janardhan N, Murali Krishna MVS, Ushasri P, Murthy PVK. Comparative studies on performance, emissions and combustion characteristics of jatropha oil in crude form and biodiesel in a medium grade low heat rejection diesel engine. International Journal of Innovative Technology and Exploring Engineering 2013; 2: 5- 15.

[34] Surendra RK, Subhash DV. Jatropha and karanj bio-fuel: an alternate fuel for diesel engine. ARPN Journal of Engineering and Applied Sciences 2008; 3: 7- 13.

[35] Sahoo PK, Das LM. Combustion analysis of Jatropha, Karanja and Polanga based biodiesel as fuel in a diesel engine. Fuel 2009: 88: 994-999.

[36] Shahir SA, Masjuki HH, Kalam MA, et al. Performance and emission assessment of diesel-biodiesel-ethanol/bioethanol blend as a fuel in diesel engines: A review. Renewable and Sustainable Energy Reviews 2015; 48: 62-78.

[37] Lei Z, Cheung CS, Zhang WG, Huang Z. Combustion, performance and emission characteristics of a DI diesel engine fueled with ethanol-biodiesel blends. Fuel 2011: 90: 1743-1750.

[38] Subramaniam D, Murugesan A, Avinash A. A comparative estimation of CI engine fuelled with methyl esters of punnai, neem and waste cooking oil. International Journal of Energy and Environment (IJEE) 2013; 4: 859- 870.

[39] Hanumantha Rao YV, Ram Sudheer V, Sitarama Raju AV, Nageswara Reddy P. Experimental investigations on jatropha biodiesel and additive in diesel engine. Indian Journal of Science and Technology 2009;2: 25- 31.

[40] Buyukkaya E. Effects of biodiesel on a DI diesel engine performance, emission and combustion characteristics. Fuel 2010; 89: 3099-3105.

[41] Huang J, Wang Y, Qin JB, Roskilly AP. Comparative study of performance and emissions of a diesel engine using Chinese pistache and jatropha biodiesel. Fuel Processing Technology 2010; 91: 1761-1767.

[42] Sathiyagnanam AP, Saravanan CG. Experimental studies on the combustion characteristics and performance of a direct injection engine fueled with biodiesel/diesel blends with SCR. In: Proceedings of the World Congress on Engineering 2011, London, UK; 6-8 July, 2011,.

[43] Meng L, Zeng C, Li Y, et al. An experimental study on the potential usage of acetone as an oxygenate additive in PFI SI engines. Energies 2016; 9(4): 256.

[44] Srithar K, Arun Balasubramanian K. Dual biodiesel for diesel engine - Property, performance and emission analysis. International Energy Journal 2014; 14: 107-120.

[45] Deepanraj B, Lawrence P, Kannan M, et al. Study on performance and emission characteristics of a compression ignition engine fueled with diesel2 ethoxy ethyl acetate blends. Engineering 2011;3(11): 1132- 1136. 
[46] Adaileh WM, AlQdah KHS. Performance of diesel engine fuelled by a biodiesel extracted from a waste cocking oil. Energy Procedia 2012; 18: 1317 - 1334.

[47] Haiter Lenin A, Ravi R, Arumugham S, Thyagarajan K. Performance, emission and combustion evaluation of diesel engine using Methyl Esters of Mahua oil. International Journal of Environmental Sciences 2012; 3, 639- 649.

[48] Baskar P, Nanthagopal K, Elango T. The effect of two oxygenates on diesel engine emissions. ARPN Journal of Engineering and Applied Sciences 2011; 6: 55- 60.

[49] Shirneshan A, Almassi M, Ghobadian B, et al. Effects of biodiesel and engine load on some emission characteristics of a direct injection diesel engine. Current World Environment 2012; 7(2): 207-212.

[50] Heywood JB. Internal combustion engine fundamentals. Singapore :McGraw-Hill; 1988.

[51] Brunt MFJ, Rai H, Emtage AL. The calculation of heat release energy from engine cylinder pressure data. SAE Technical Paper: 98105; 1998. 